\title{
Using the RE-AIM framework to evaluate safe food village development programme through the food safety movement in village in the Special Region of Yogyakarta, Indonesia
}

\author{
Rizqi Amalia Rohmah ${ }^{1,2}$, Yayi Suryo Prabandari ${ }^{1 *}$, and Lily Arsanti Lestari ${ }^{1}$ \\ ${ }^{1}$ Public Health Science Study Programme, Faculty of Medicine, Public Health and Nursing, Universitas Gadjah Mada, \\ Jl.Farmako Sekip Utara, Yogyakarta, 55281, Indonesia \\ ${ }^{2}$ Provincial Office of the National Agency of Drug and Food Control (NADFC), Yogyakarta, Indonesia
}

\begin{abstract}
Unsafe food is a major threat to public health both globally and in the Southeast Asia region. In Indonesia, various food safety problems are still encountered such as cases of food poisoning, food containing hazardous materials and poor food handlers' sanitation hygiene. One of The National Agency of Drug and Food Control (NADFC)'s efforts to overcome food safety issues in Indonesia is the development of safe food villages with village community-based food safety interventions through the Food Safety Movement in Village (Gerakan Keamanan Pangan Desa/GKPD). The study used RE-AIM framework with a case study design. The study sites were Pandowoharjo Village, Sendangsari Village and Mangunan Village, the Special Region of Yogyakarta, Indonesia. Informants were selected purposively as many as 73 people. Data were collected through six FGDs, 16 interviews face to face and using telephone, observation and document review. The analytical approach used was qualitative content analysis with Opencode software version 3.6.2.0. The results of the study showed that the GKPD program involved community policy makers (village officials), the formation of food safety cadres from various community groups (family health empowerment organization, youth organizations, teachers) and the fostering of various food provider communities in the village (housewives, home-industries, food retailers, school canteen, and street food vendors), as well as the involvement of public health centre, but in its implementation there were obstacles to the adoption of food safety practices by the food vendors community which caused the program to not be fully effective in changing food safety behaviour due to economic and human resources factors.
\end{abstract}

\section{Introduction}

Foodborne disease has a significant influence on economic development and international trade. Local incidents can quickly become an international emergency because of the speed and range of food distribution that impacts health, economy and trade [1]. WHO estimates that there are 31 foodborne hazards that could cause 600 million cases foodborne diseases and 420000 deaths in 2010 [2]. WHO stated, in 2016 the economic impact of foodborne disease in low and middle income countries in Asia is estimated at no less than USD 63.1 billion [1].

Food safety is related to achieving Sustainable Development Goals (SDGs) such as zero hunger, good health and well-being, no poverty, gender equality, access to clean water and sanitation, responsible consumption and production, and handling climate action. The integral role of food safety in achieving SDGs was highlighted during the International Food Safety Conference in Addis Ababa in early 2019. SDGs would not be achieved without adequate, safe and healthy food, especially for domestic consumers in developing countries [1].

In Indonesia, outbreaks of food poisoning in the period 2000-2015 were 61119 cases out of 715579 at risk population ( $8.5 \%$ attack rate) and 291 deaths (case fatality rate $0.4 \%$ ). Based on the type of food processing activities, routine food (36.6\%) and special food $(29.7 \%)$ are the most at risk with the highest case area in residential $(48.9 \%)$ and schools $(13.7 \%)$. Household cooking $(46.9 \%)$ and service food $(18.9 \%)$ are the highest foods as cause of poisoning with the most frequent causative agents being pathogenic bacteria (74.9\%) with E. coli as the main cause (20\%) [3].

One of the efforts undertaken by NADFC to overcome food safety problems in Indonesia is the development of safe food villages through the Food Safety Movement in Village (Gerakan Keamanan Pangan Desa/GKPD). GKPD, that was initiated by the NADFC since 2015, is a community empowerment movement aimed at increasing the independence of village communities in ensuring the fulfillment of safe food needs up to the individual level and strengthening the village economy, with a supply-side approach

* Corresponding author: yayisuryo@ugm.ac.id 
through Micro Small Medium Entrepreneur (MSME) development and demand-side through empowerment cadres and village communities $[4,5]$. The purpose of community empowerment is to increase individual and community awareness of health issues and increase competence, so that they can independently improve their health [6].

Based on the GKPD report from 2014-2019, GKPD program is implemented in 33 provinces in Indonesia in 810 villages, trained 9249 village food safety cadres and fostered 46251 village communities [7]. In the Special Region of Yogyakarta, the GKPD program is run by Provincial Office of the NADFC in Yogyakarta. Data 2014 - 2019 shows that the GKPD program in Special Region of Yogyakarta has been implemented in five districts/cities, 29 villages, trained 309 village food safety cadres and built 1702 village communities [7].

The characteristics of the villages that were intervened by the GKPD program in Yogyakarta were villages that had a commitment of food safety, had food providers such as home industries, street vendors, retails and school canteens, had active PKK (Pemberdayaan Kesejahteraan Keluarga/family health empowerment organization) and youth organizations and were supported by the local district health office.

The RE-AIM model was developed in 1999 to evaluate public health interventions. The five dimensions of RE- AIM measurement are reach, effectiveness, adoption, implementation, and maintenance [8]. Qualitative approaches in the RE-AIM model are used for several reasons: some questions cannot be answered with quantitative data, qualitative data provides answers to the questions "why" and "how" things happen, the availability of diverse assessment methods to provide convergent validity for quantitative results, can involve participants collaboratively and consider their input to a program or policy in a way that is not carried out by a quantitative approach [8]. The use of the RE-AIM framework to evaluate the GKPD food safety intervention program in three intervention villages is expected to be used to describe and assess program interventions more comprehensively.

This is the first study to use the RE-AIM framework in evaluating the GKPD program.

\section{Methods}

This research is a qualitative evaluation method with a case study research design. The study was conducted in Pandowoharjo Village, Sendangsari Village and Mangunan Village, Special Region of Yogyakarta, Indonesia, in January - May 2020 after ethical clearance was issued by the Medical and Health Research Ethics Committee UGM. The three sites were chosen because the three villages were the intervention villages of the GKPD in 2019, so that was easier to coordinate with the parties involved in the program.

Informants were selected purposively related to implementing the GKPD program in three villages. The inclusion criteria used for informants were cadre who had attended village food safety cadre training on 27-28 March 2019, village communities who had attended community training in July 2019, village heads or representatives of the village food safety team. There were 73 informants consisting of 28 village food safety cadres, 31 village communities, three village communities who were exposed but not involved as cadres/communities, three village heads/village food safety teams, three public health centre officers, two health service officials, two officials structure of the health service and one Provincial Office of the NADFC in Yogyakarta officer.

Data collection methods used were six FGDs, 16 indepth interviews face to face and using telephone, document review and observation. Data were collected at the village hall, at the informant's house or at the informant's office. The researcher was the main research instrument, female gender, master's student in public health science who get courses on qualitative research. Researcher conducted FGDs, in-depth interviews, document review and observation in this research. The supporting instrument were the FGD guidelines, interview guidelines and document review lattices. The data credibility of this study used triangulation of sources and methods of data collection, member checking and peer de briefing. The data analysis approach used was qualitative content analysis using Opencode version 3.6.2.0 software.

The operational definitions used in the study can be seen in Table 1.

Table 1. Operational Definition

\begin{tabular}{|c|l|}
\hline Dimension & \multicolumn{1}{|c|}{ Operational Definition } \\
\hline Reach & $\begin{array}{l}\text { Those who are exposed to the GKPD } \\
\text { program, benefit, actively participate or not, } \\
\text { as well as factors that contribute to } \\
\text { participation/non-participation. Non- } \\
\text { participation means parties who are exposed } \\
\text { to and benefit from the program } \\
\text { but are not active as village food safety cadres } \\
\text { or trained village communities. }\end{array}$ \\
\hline \multirow{5}{*}{ Effectiveness } & $\begin{array}{l}\text { How does the intervention achieve its } \\
\text { objectives, the factors that contribute to the } \\
\text { results achieved as well as the presence or } \\
\text { absence of negative results } \\
\text { from the intervention }\end{array}$ \\
\hline Adoption & $\begin{array}{l}\text { Acceptance of the program, those who } \\
\text { implement the program or policy }\end{array}$ \\
\hline Implementation & $\begin{array}{l}\text { A description of the implementation at the } \\
\text { time the intervention was carried out, the } \\
\text { parties involved, the time of implementation, } \\
\text { the factors influencing } \\
\text { the implementation and the obstacles }\end{array}$ \\
\hline $\begin{array}{l}\text { Interventions carried out after the core period } \\
\text { of intervention, an overview of all things that } \\
\text { are ongoing, all things that } \\
\text { were stopped, what was changed and the } \\
\text { cause. }\end{array}$ \\
\hline Maintenance
\end{tabular}

\section{Results}

\subsection{Setting}

GKPD in three intervention villages is a program initiated by Provincial Office of the NADFC in Yogyakarta in 2019. The activity began with village 
advocacy activities in February 2019 until monitoring and evaluation activities in November 2019. This research was carried out when the GKPD program was completed in three intervention villages.

\subsection{Reach}

Table 2. "Reach" categories \& subcategories

\begin{tabular}{|c|c|}
\hline Categories & Subcategories \\
\hline Participant & $\begin{array}{c}\text { Village officials; community; food } \\
\text { vendors; public health centre }\end{array}$ \\
\hline $\begin{array}{c}\text { Factors that } \\
\text { encourage } \\
\text { participation }\end{array}$ & $\begin{array}{c}\text { Community food safety conditions; } \\
\text { hope for the benefits of the program }\end{array}$ \\
\hline $\begin{array}{c}\text { Selection of } \\
\text { participants }\end{array}$ & $\begin{array}{c}\text { Meet the village criteria; village food } \\
\text { safety cadre criteria; village } \\
\text { community }\end{array}$ \\
\hline $\begin{array}{c}\text { Factors that inhibit } \\
\text { participation }\end{array}$ & $\begin{array}{c}\text { Limitation on the number of } \\
\text { participants, cadre/community } \\
\text { conditions, technical obstacles in the } \\
\text { field }\end{array}$ \\
\hline $\begin{array}{c}\text { Parties exposed to } \\
\text { cadres/ } \\
\text { communities }\end{array}$ & \begin{tabular}{c} 
Communities \& village food vendors \\
\hline
\end{tabular} \\
\hline
\end{tabular}

In the "reach" dimension, the program involved the community components. There are factor that encourage and inhibit participation in the program.

\subsection{Effectiveness}

Table 3. "Effectiveness" categories \& subcategories

\begin{tabular}{|c|c|}
\hline Categories & Subcategories \\
\hline $\begin{array}{c}\text { Food safety } \\
\text { knowledge and } \\
\text { practices }\end{array}$ & $\begin{array}{c}\text { Increase the knowledge of cadres/ } \\
\text { communities involved; safety practices } \\
\text { have not been carried out consistently }\end{array}$ \\
\hline $\begin{array}{c}\text { Contributing } \\
\text { factors }\end{array}$ & $\begin{array}{c}\text { The cadre is less active; short food } \\
\text { safety exposure }\end{array}$ \\
\hline Negative impact & $\begin{array}{c}\text { The majority did not convey negative } \\
\text { impacts }\end{array}$ \\
\hline
\end{tabular}

In the "effectiveness" dimension, the program increases the knowledge of cadres/communities involved but food safety practices have not been carried out consistently, with contributing factors such as the presence of cadres who are less active and short exposure to food safety.

\subsection{Adoption}

Table 4. "Adoption" categories \& subcategories

\begin{tabular}{|c|c|}
\hline Categories & Subcategories \\
\hline $\begin{array}{c}\text { The party who } \\
\text { applies }\end{array}$ & $\begin{array}{c}\text { Household; village food vendors; } \\
\text { schools, PKK organizations }\end{array}$ \\
\hline $\begin{array}{c}\text { Barriers to } \\
\text { adoption }\end{array}$ & $\begin{array}{c}\text { Economic conditions, human } \\
\text { resources, youth organization }\end{array}$ \\
\hline
\end{tabular}

In the "adoption" dimension, there are obstacles to adoption of community food safety practices and food vendors because of economic and human resources factors, as well as obstacles to the adoption of programs by youth organization.

\subsection{Implementation}

Table 5. "Implementation" categories \& subcategories

\begin{tabular}{|c|c|}
\hline Categories & Subcategories \\
\hline $\begin{array}{c}\text { Implementation } \\
\text { of the program }\end{array}$ & $\begin{array}{c}\text { Community assessment; building } \\
\text { commity capacity; involving the role } \\
\text { of communities and public health } \\
\text { centrenitoring \& evaluation }\end{array}$ \\
\hline Obstacle & Technical implementation \\
\hline
\end{tabular}

In the "implementation" dimension, the program building community capacity, involving the role of local communities by forming community health worker (cadre) and regional health coaches.

\subsection{Maintenance}

Table 6. "Maintenance" categories \& subcategories

\begin{tabular}{|c|c|}
\hline Categories & Subcategories \\
\hline $\begin{array}{c}\text { Follow-up program } \\
\text { by cadres }\end{array}$ & $\begin{array}{c}\text { Disseminating information incidentally; } \\
\text { utilization of promotional materials and } \\
\text { test kits was not optimal }\end{array}$ \\
\hline Budgeting & $\begin{array}{c}\text { Village budgeting 2020; stakeholder } \\
\text { synergy }\end{array}$ \\
\hline $\begin{array}{c}\text { Barriers to program } \\
\text { follow-up }\end{array}$ & $\begin{array}{c}\text { Limited resources; cadres / } \\
\text { communities feel less confident; busy }\end{array}$ \\
\hline Monitoring & Do not run routinely \\
\hline
\end{tabular}

In the "maintenance" dimension, follow-up on disseminating information by cadres has not been programmed regularly, program budgeting using the 2020 village budget with special activities or integrated other programs as well as synergy with regional stakeholders, program monitoring has not been running routinely and optimally

The results of the study showed that the GKPD program involved saveral community in village, but in its implementation there were obstacles to the adoption of food safety practices by the food vendors community which caused the program to not be fully effective in changing food safety behaviour due to economic and human resources factors.

\section{Discussions}

Food safety interventions in Pandowoharjo Village, Sendangsari Village and Mangunan Village by Provincial Office of the NADFC in Yogyakarta in 2019 were top-down through the supply-side approach of developing village MSMEs in the field of food and demand-side by empowering cadres and village communities. In the top-down program, identification of problems comes from health practitioners in the upper 
structure descending to the community [6]. The program design was carried out according to NADFC technical guidelines, including the determination of the parties involved in the program. According to Laverack (2007), health practitioners as leaders of health promotion programs usually choose the design, means of program implementation and evaluation, the selection of target groups and the methods used to reach the target groups and the approaches used.

The parties involved and participating in the GKPD program were the village official, the community, namely the $\mathrm{PKK} /$ housewives, youth and elementary school teachers, as well as food vendors, namely the food home-industries, street vendors, food retailers and school canteens that have already determined amount. The program also involves health agencies, namely the public health centre and local health offices. The involvement of health agencies in the program is in line with Law Number 18 of 2012 concerning Food. Article 68 paragraph (1) states "The Government and Regional Governments guarantee the realization of integrated food safety in each food chain".

Village selection criteria were determined by Provincial Office of the NADFC in Yogyakarta. Involved in the program were the village heads who have a commitment to food safety, the village has micro small and medium vendors in the food sector, has an active PKK organization and village cadets, based on a proposal from the health office at the request of Provincial Office of the NADFC in Yogyakarta. The village head's commitment assessment was carried out by Provincial Office of the NADFC in Yogyakarta with direct interviews related to the willingness and commitment to run the program. A study of 124 cadres in Mlonggo Subdistrict, Jepara showed that the leadership of the village head was significantly related to the attitude of the posyandu cadre [9]. Several factors that encourage government and community participation in the program include the presence of unsafe food, the presence of food poisoning cases, and the lack of public knowledge and awareness related to safe food, the monitoring data of Provincial Office of the NADFC in Yogyakarta food products in Yogyakarta in 2019 showed from 901 random food samples tested chemical and/or microbiological parameters, there were $68 \%$ fulfilling the requirements in labeling and / or laboratory testing [10].

The benefit factor that will be obtained is also a factor that encourages the community to become cadres and vendors people following the food safety technical assistance program. Expected benefits include increasing food safety knowledge, being able to apply food safety practices, being able to foster students choosing safe snacks, increasing the quality of food vendors and hoping that the case of poisoning will not happen again.

Community participation and village food vendors in the program were hampered by restrictions on the number of participants, namely 15 cadres from three groups (PKK, teachers, youth) and 50 communities from the community and vendors from five village community groups (PKK/housewives; food homeindustries, canteen school, and street vendors). The amount of community participation was very small compared to the number of residents in each village. Pandowoharjo Village has 12188 peoples, Sendangsari Village has 4628 peoples and Mangunan Village has 4 654 peoples. The village government seeks to represent cadres and communities from each village. Barriers to program participation were also found due to the busy schedule of cadres working or studying. Work activities in the school stall or canteen also hamper program participation.

"If I hear that, she said indeed ... she didn't have time

... because she opened the shop from 6 in the morning until the evening ... Then there was no substitute ..." (KU, women, street vendors)

Research data shows that food safety interventions through the cadre of technical guidance and community technical assistance increase the knowledge of cadres/communities involved. The informant said that they got new information about food safety and could test materials suspected of containing hazardous materials by using a test kit.

Then e ... if you choose the food in the package, you have to look at the contents, what kind of packaging, airtight, expiration date, still good packaging or dent, then there is expired ... then the nutritional content is like anything. so .. "(P-3, women, parties exposed not cadres / communities). This is different from the study using secondary data on a quantitative action survey of street food vendors for school children in 20 provinces in Indonesia, which shows that there is no significant effect of school programme on the knowledge of food safety of vendors at school [11].

Although the informant said that he got the knowledge, but observations of food safety practices conducted by researchers showed that safety practices have not been carried out consistently. This is evident among other things from the use of apron and headgear that is not consistent, clips are still found to wrap food and food packaging is not registered. This is consistent with research on 400 food handlers around Greater Jakarta Elementary School which shows that the handlers have very good knowledge and attitude, but lower practices related to food hygiene and sanitation [11]. Research on 183 food handlers in Santos Brazil shows that training based on theoretical aspects is not related to attitudes, self-reported practices and observed practices of food handlers but is effective in increasing knowledge [12]. The results of the study differed from studies in communities that received the same interventions of the GKPD program in DKI Jakarta Province which showed that food safety knowledge significantly affected attitudes and behaviours of food safety [13]. The difference in the results of this study is due to the different ways of measuring safety practices by researchers. In this study, researchers assessed food safety practices by direct observation while the EllindaPatra et al. (2020) with a questionnaire filled in by respondents.

Knowledge is a fundamental part of food safety behaviour and practices, but it is not enough to ensure adequate food safety practices. Knowledge allows food 
handlers to change practices if they are motivated to change their behaviour [12]. According to Schafer et al. (1993), the factors that predict food safety measures according to the Health Belief Model theory are the perception that unsafe food is a threat to personal health, the perception that a person can do something related to threats (self-efficacy), and motivation to maintain good health. People who feel a personal threat and believe that they can do something about it tend to be involved in food safety behaviour [14].

The factors that influence inconsistent practices include the presence of cadres who are less active in providing assistance to the community, and only brief food safety material exposure. During the program intervention, the cadres received food safety training for two days, while the village community attended the one day training by assisting food safety practices by the cadres in each kitchen for two times. Research in British-Columbia Canada shows that the knowledge of Food safe-trained food handler groups that receive significantly higher retraining than those who do not receive retraining or who are not trained [15]. The effectiveness of cadres depends on the cadre's relationship with the community. The social complexity and diversity of the community must be recognized by program planners and provide cadres with appropriate interaction and mutual respect for all members of the community [16].

Factors that influence barriers to the adoption of food safety practices by the community of rural food vendors include limited economic conditions so that production/distribution infrastructure that supports food safety was also limited, and human resource factors. Lack of food safety equipment is a major barrier to behaviour change in food handling practices among food providers in Ghana as far as food handling practices are concerned [17]. The limitations of school canteen infrastructure such as a narrow canteen and the lack of running water facilities was one of the factors that influence canteen food safety practices in schools. Human resource factors that are obstacles to the adoption of food safety practices include the mindset of not wanting to bother, awareness, and daily habits run by the community.

The adoption of food safety guidance was carried out by the PKK through the PKK routine meeting forum. The GKPD program is closely related to Work Group III in the fields of food, clothing, housing and household management, and Work Group IV in the fields of health, environmental sustainability and healthy planning. Obstacles to the adoption of organization-level programs were found in the youth organization because so far the youth work program was more directed towards the development of youth, human resources and sports, and has not yet adopted the GKPD program model.

One of the strategies of the GKPD program is to build community capacity through village institutional advocacy activities, village food safety cadres, village community technical assistance and facilitation of food safety implementation visits. The capacity of village communities is strengthened so that community members can solve their own problems by developing specific skills and competencies that contribute to overall capacity [18]. Figure 1 is the stage of GKPD activities in three intervention villages.

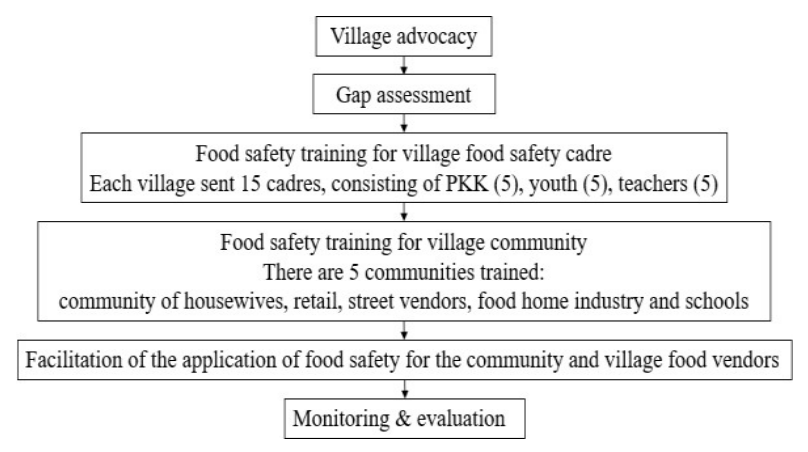

Fig. 1. Stages of GKPD program implementation

The implementation of the GKPD involves the role of community leaders in the village as village food safety cadres tasked with fostering the PKK/household community, food retailers and school canteens. Community health workers, in this case, cadres can function as a bridge between professional health staff and the community, help communities identify and address their own health needs, help mobilize community resources and build local capacity [16]. In this GKPD program, the characteristics of village food safety cadres include cadres trained for several days, working as volunteers, working several hours when there are activities with limited scope of duties and responsibilities, as well as functioning independently but can be connected to local public health centre staff. Various characteristics of public health workers in the world, some trained for several days of training and some for six months or more, some are paid with salaries and others work as volunteers, some work full time and others only a few hours a week, some have a variety of tasks and responsibilities while others have limited scope of work, some have close interactions with health staff and others operate far away and function independently [19].

Public health centre staff and health offices involved in the GKPD program are tasked with fostering the food home-industries and street vendors communities. In accordance with Law Number 23 of 2014 concerning Regional Government which was last amended by Law Number 9 of 2015, district/city regional governments, in this case district/city health offices, carry out the issuance of food and beverage production permits in the home industry household and carry out post-market supervision of household food and beverage products. The development of the food home-industries community in the GKPD program is expected to continue until the product obtains a certificate P-IRT distribution permit from the health office for products that are circulated in retail and label packaging, but in practice, some products do not meet the criteria because the product shelf life is less than seven days, implicating on mismatch of facilitation forms used and does not continue to obtain a marketing authorization. This is due to the fact that in some villages the number of producing packaged food that has a shelf life of more than seven 
days is small so that vendors that make snacks for a shelf life of less than seven days and are not required to have a distribution permit are included in this IRTP community group.

After the intervention of the GKPD program ends, the village food safety cadres independently disseminate information on integrated food safety in other activities such as the routine PKK village/dukuh/RT forum and posyandu meetings. This socialization activity was incidental and has not been programmed regularly. Special follow-up that was carried out independently related to the GKPD program was the socialization of "Nutritious and Healthy Food for Children" in the Parents Association of Students of SDN Mangunan by involving cadres, public health centre sanitary officers, parents of students and all food retailers around the school. Promotional materials and rapid test kits for testing foods that were suspected of containing hazardous substances were used during interventions and have not been used optimally by cadres after the intervention ends.

As a follow-up to the program in particular, the Village Government of Mangunan through the village budget in 2020 has budgeted training programs for food stalls in tourist villages for 40 people. While the Pandowoharjo and Sendangsari Villages do not budget for specific activities but synergize food safety with the development of MSMEs as well as counseling and training in the health sector in Pandowoharjo Village and the provision of posyandu supplementary food programs in the Sendangsari Village.

The public health centre followed up on integrated community development with the food sanitation hygiene program as well as routine food processing monitoring activities in three intervention villages. Whereas the health department conducts a follow-up in collaboration with the supervisor of the post-market supervision of food products that have obtained a P-IRT permit. The Sleman District Health Office budgeted a workshop on developing safe food villages in 2020 with a plan to involve all village food safety cadres in Pandowoharjo Village and Sendangsari Village located in Sleman Regency.

Limited resources to improve the school canteen, limited health centre resources and the health office, the presence of cadres/communities feeling less confident because they feel that they had limited experience, busyness of cadres in school work, busy preparing preeminent village competitions or busy work or college cadres become obstacles to follow-up the GKPD program after the end of the mentoring. In general, there has been no specific follow-up carried out programmatically by food safety cadres in three villages. Cadre's internal factors such as age, length of dedication, experience, social status, economic situation and family support, as well as external factors such as the condition of the community and health agencies influence the motivation and retention of cadres [20].

Program monitoring from cadres to the community and from BPOM to cadres is not yet running. BPOM has scheduled monitoring to the village to take place after one year of intervention. According to Bhattacharyya et al. (2001), when supervision is inconsistent, cadres may feel unsupported by the health system. Ensuring that supervisors are trained to supervise and request community involvement in supervision can increase cadre retention and help ensure the long-term sustainability of cadres in the community.This study has several limitations. Research time is limited so that the method of selecting village community informants selected purposively based on information from village food safety cadres. Some of the interview data collection in this study was done used the telephone because of the Covid-19 pandemic situation, the researcher cannot read the informant's non-verbal cues during the interview. Observation of village community food safety practices in Pandowoharjo Village and Sendangsari Village only be done on a limited basis because of the Covid-19 pandemic situation. Observation of food safety cadres spreading food safety information to the public could not be carried out because the the condition of the Covid-19 pandemic. This study evaluated the 5 dimensions of RE- AIM conducted in 3 intervention villages during the limited time of the study, so that the evaluation obtained had a breadth of results but in each dimension, it was not deep.

\section{Conclusion}

Using the RE-AIM framework as a program evaluation framework, an overview of the health promotion program for safe food village development through GKPD was carried out by Provincial Office of the NADFC in Yogyakarta in 2019 in three intervention villages. The design of the GKPD program developed by NADFC nationally has the advantage of involving community components ranging from policy makers, forming food safety cadres from various community groups and fostering various food vendors communities in the village, but in its implementation, there have been obstacles to the adoption of food safety practices by the village food vendors community which ultimately led to the program not being fully effective in changing behaviour in terms of food safety practices. The evaluation results can be used as an input for Provincial Office of the NADFC in Yogyakarta's continuous improvement in Yogyakarta in an effort to develop more effective health promotion programs.

This research result is expecting to encourage policies to strengthen village capacity and empower village communities in term of food safety, promote public health with a more effective food safety training design and regular monitoring, and the RE-AIM framework can be used to evaluate health promotion program in Indonesia.

\section{References}

1. WHO Regional Office for South-East Asia, Framework for Action on Food Safety in the WHO South-East Asia Region. New Delhi, (2020).

2. WHO, WHO Estimates of the Global Burden of Foodborne Diseases: Foodborne Disease Burden Epidemiology Reference Group 2007- 2015, Switzerland, (2015). 
3. R.R. Arisanti, C. Indriani, S.A. Wilopo, Ber. Kedokt. Masy., 34,3, 99-106 (2018).

4. BPOM, Kerangka Acuan Kerja Gerakan Keamanan Pangan Desa Tahun 2018, (2018).

5. BPOM, Petunjuk Teknis Desa Pangan Aman untuk Balai Besar/Balai/Loka POM, Jakarta, (2020).

6. G. Laverack, Health Promotion Practice Building Empowered Communities. New York: Open University Press, (2007).

7. BPOM, Hasil Kegiatan Gerakan Keamanan Pangan Desa (GKPD) Tahun 2014-2019, Jakarta, (2020).

8. J.S. Holtrop, B.A. Rabin, R.E. Glasgow, BMC Health Serv. Res., 18,1, 1-10 (2018).

9. L. Widagdo, Makara J. Heal. Res., 10,2, 54-59 (2006).

10. BBPOM di Yogyakarta, Laporan Tahunan 2019 Balai Besar POM di Yogyakarta, Yogyakarta, (2020).

11. L. Cempaka, A.A. Rizki, N. Asiah, Asian Pasific J. Sustain. Agric. Food Energy, 7,2, 1-8 (2019).

12. D. Thimoteo, E. Stedefeldt, V.V. De Rosso, Food Control, 43, 167-174 (2014).

13. M. Ellinda-Patra, R. Dewanti-Hariyadi, B. Nurtama, Food Res., 4, 1045-1052 (2020).

14. R.B. Schafer, E. Schafer, G.L. Bultena, E. O. Hoiberg, J. Nutr. Educ., 25,1, 17-24 (1993).

15. L. Mcintyre, D. Peng, S. B. Henderson, Food Control, 35,1, 137-141 (2014).

16. K. Bhattacharyya, P. Winch, K. LeBan, M. Tien, Community Health Worker Incentives and Disincentives: How They Affect Motivation, Retention, and Sustainability. Virginia: Basic Support for Institutionalizing Child Survival Project (BASICS II) for the United States Agency for International Development, (2001).

17. E.S. Donkor, B.B. Kayang, J. Quaye, M.L. Akyeh, Int. J. Environ. Res. Public Health, 6, 2833-2842, (2009).

18. R. Labonte, G. Laverack, Health Promotion in Action From Local to Global Empowerment. England: Palgrave Macmillan (2008).

19. H. Perry, R. Zulliger, How Effective Are Community Health Workers? An Overview of Current Evidence with Recommendations for Strengthening Community Health Worker Program to Accelerate Progress in Achieving the Health-related Millenium Development Goals. Amerika: Johns Hopkins Blommberg School of Public Health (2012).

20. D.N. Ismarawanti, J. Manaj. Pelayanan Kesehat., 13,4, 169-173 (2010). 